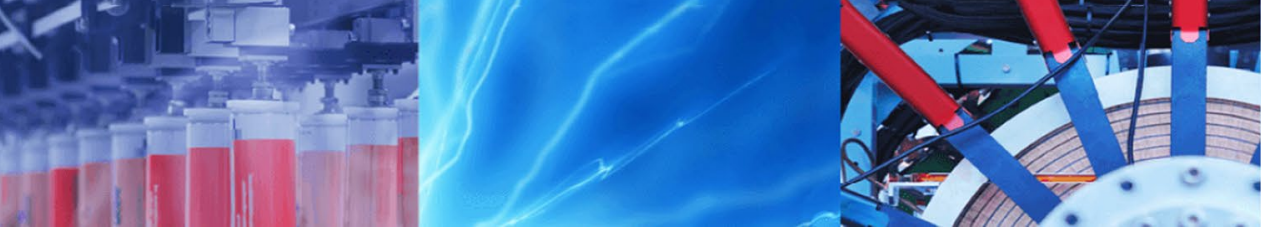

Research Article

\title{
Role of Prosopis juliflora biochar in poly-aromatic hydrocarbon remediation using Trifolium alexandrinum L.
}

\author{
Varinder Kaur ${ }^{1} \cdot$ Praveen Sharma $^{1}$
}

(c) Springer Nature Switzerland AG 2019

\begin{abstract}
Biochar possesses a number of characteristics that make it suitable for remediation of organic and inorganic pollutants from soil. Biochar acts as a suitable amendment to the soil as it increases the surface negative charge, nutrient retention capacity, high adsorption affinity, porosity, resistance to degradation and a high internal surface area. The present research is based on pot experiment, from October 2015 to April 2016. A probe sonicator extraction procedure was used for the determination of naphthalene and phenanthrene in dried soil and plant samples using gas-chromatography coupled with flame ionization detector. Fortification was carried out by spiking the $50 \mathrm{mg} / \mathrm{kg}$ naphthalene and $100 \mathrm{mg} /$ $\mathrm{kg}$ phenanthrene in soil. The extraction efficiency observed for phenanthrene was $74.62 \%$ and $66.59 \%$ for naphthalene with relative standard deviation in the range of 0.39 to 0.26 , respectively. Naphthalene was not detected in soil and plant samples. BCF value significantly decreases with increasing the biochar concentration in soil as compared to control (nonbiochar-amended soil). BCF level decreased significantly $(P \leq 0.05)$ from 123.1 to 4.46 in phenanthrene-contaminated soil and 19.3-1.32 in mixed contaminated soil with time period. The maximum phenanthrene removal efficiency is observed to be $10 \%$ in biochar-amended soil as compared to other treatments $(10 \%>5 \%>1 \%>$ control). Biochar significantly helps to increase plant height, dry biomass and total available nutrients. Above results showed that biochar derived from Prosopis juliflora effectively enhanced the PAHs surface adsorption capacity, removal efficiency and plant growth parameters. This study shows the effectiveness of biochar on contaminant remediation with the help of Trifolium alexandrinum.
\end{abstract}

Keywords Biochar · Poly-aromatic hydrocarbon · Adsorption capacity · Trifolium alexandrinum

\section{Introduction}

Globally, biodiversity reduces due to the natural (includes volcanic eruption, forest fire and floods) and anthropogenic activities (includes industrial waste disposal sites, excessive use of pesticides and fertilizers in cropland, urbanization, automobiles and incomplete combustion of plant biomass) $[7,45]$ that may directly affect the soil health. The uncontrolled use of chemicals and inorganic fertilizers in agricultural practices is the main problem for increasing the intensity of different contaminants in cropland. These activities are the main cause for the loss of productive soil for agriculture by releasing harmful organic and inorganic contaminants in soil and harsh natural environmental conditions [4]. Moreover, soil performs as a natural sink for many harmful toxicants that over the time accumulates and concentrates in soil from different sources [34].

The list of 16 poly-aromatic hydrocarbons (PAH) has been identified by United States Environmental Protection Agency (USEPA) on the basis of their toxicity. Some of these contaminants are listed in Figs. 4 and 5 in electronic

Electronic supplementary material The online version of this article (https://doi.org/10.1007/s42452-019-1056-5) contains supplementary material, which is available to authorized users.

Praveen Sharma, ps.enbt@gmail.com; Varinder Kaur, varinder.kaur265@gmail.com | 'Department of Environmental Science and Engineering, Guru Jambheshwar University of Science \& Technology, Hisar, Haryana, India.

SN Applied Sciences (2019) 1:1064 | https://doi.org/10.1007/s42452-019-1056-5

Received: 25 March 2019 / Accepted: 7 August 2019 / Published online: 21 August 2019 
supplementary material low molecular weight (LMW) and high molecular weight (HMW) PAHs, respectively. These PAHs are lipophilic chemical compounds that are found in the soil, water and plant bodies mainly due to wet and dry deposition activities of atmosphere [33]. PAHs are generally insoluble or less soluble in water, and their solubility decreases with increasing molecular weight [1]. PAH compounds are highly toxic and dangerous for our environment as well as human health [41]. The main root of exposure of these PAHs into environment is combustion of carbonaceous material, motor vehicle emissions and smelting [1]. HMW PAHs negatively effect soil quality, crop production and soil microbial diversity, and LMW PAHs are also toxic in nature [3].

This problem could be overcome by using biochar which is a stable form of charcoal derived from different agricultural byproducts, forest residues, sewage waste, animal excreta and dairy manure materials [28]. According to the International Biochar Initiative (IBI), Kaur and Sharma $[21,22]$, "Biochar is a solid material obtained from thermochemical conversion of biomass in an oxygen-limited environment". Biochar contains the carbonized and non-carbonized organic matter such as wood fiber cellulose and lignocellulose [11-13]. Biochar has the potential to retain nutrients required for plant growth and productivity [25]. It nourishes soil by increasing the water holding capacity and soil porosity that helps to reduce the soil bulk density especially in case of sandy soil having high bulk density and low water retention capacity [9].

Biochar is a carbonaceous substance and has strong adsorption capacity for all contaminants present in the soil. Hence, it can be used as a powerful tool for sustainable agriculture and rendering agro-ecosystems more stress-free. The remediation efficiency of biochar helps to remove pollutants that may be organic or inorganic in nature $[19,35]$. The mechanism for reduction in organic and inorganic contaminants in soil and plants depends upon biochar adsorption capacity, surface area and porosity which again depend upon production temperature, feedstock quality used during production of biochar [3].

It improves soil fertility due to its high surface area, electrostatic attractions and highly porous structure [42, 43]. Therefore, biochar applications in soil help to improve soil physical, chemical and biological properties because it has the ability to remain in the soil for hundreds to thousands of years $[37,44]$.

The different applications of biochar are shown in Fig. 6 in electronic supplementary material. Additionally, treatment of soil with biochar or biochar compost can be justified as cheaper or economical approach [35, 44].

Moreover, the other benefits of biochar as soil amendment resolve many environmental issues such as production of bio-energy, waste management, enhancing soil productivity and quality by changing soil $\mathrm{pH}$, cation exchange capacity (CEC), organic carbon content, nutrient retention capacity and water holding capacity $[38,40]$.

In present research, berseem (Trifolium alexandrinum) was used as a test crop. It is an important forage, fast growing, leguminous, winter season crop and neutral to alkaline soils. It belongs to Fabaceae family. Berseem also acts as a phytoaccumulator, when grown on polluted soil [8]. It has a tendency to absorb large amount of pollutants from soil that causes serious health effects to human beings, animals and on environment. The level of pollutants in fodder crops generally depends on climatic conditions, agro-chemical practices, soil type and irrigated water quality [8]. According to [15], Trifolium pretense L. species was used as a phytoaccumulator for removal of PAH contaminated soil. Moreover, no literature was found that shows the phytoaccumulator efficiency of Trifolium alexandrinum species with respect to PAHs. Biochar-treated plots were compared with non-biochar-treated plots, and the maximum increase in berseem fodder and seed yield was reported in biochar-treated soil at the dose rate of 25 and 50 ton ha ${ }^{-1}[14]$.

This research has been focused on the synthesis of biochar from Prosopis juliflora (P. juliflora) which is potentially valuable and sustainable tool to improve soil quality and berseem growth. P. juliflora biochar could be used as an adsorbent for the removal of pollutants present in the soil [27]. It helps to resolve environmental problems faced by rapidly developing society and increasing population worldwide.

For these reasons, the application of biochar has recently been suggested as a sustainable means to agroeconomic benefits, i.e., improved fertility, increased nutrient cycling and environmental benefits. To our knowledge, no previous research has systematically investigated to study the effect of separate and combined doses of biochar-amended soil with PAHs on berseem growth parameters. This research highlighted that the application of biochar in contaminated soil improves berseem growth and plant available nutrients as compared to control. P.juliflora biochar reduces sandy soil bulk density with increasing surface porous structure and water holding capacity.

Therefore, the objectives of this work was to understand the: (1) physico-chemical characterization of soil and biochar produced from P. juliflora, (2) to evaluate the effect of different doses of biochar on plant height, biomass and chlorophyll content at different time intervals, (3) to study the dose effect of biochar on PAHs adsorption capacity at different durations. 


\section{Materials and methods}

\subsection{Experimental design}

\subsubsection{Sample collection}

The pot study was conducted from October 2015 to April 2016 in replicates under natural conditions in University Energy Park, Guru Jambheshwar University (Coordinates $\left.29.1672^{\circ} \mathrm{N}, 75.7401^{\circ} \mathrm{E}\right)$, Hisar, India. The P. juliflora biochar was procured from $\mathrm{C} 6$ Agrisciences India private limited, Telangana, Hyderabad, India. It was synthesized by traditional earth mound kiln method at approximately $450^{\circ} \mathrm{C}$ [36]. It was crushed to homogenize before pot filling. The air-dried soil was collected from nursery area in the University. Soil and $P$. juliflora biochar were subsequently sieved to pass through a 2-mm sieve and stored in laboratory at room temperature for further experimental analysis. Different concentrations of biochar $(0 \%, 1 \%, 5 \%$ and $10 \%)$ were then mixed homogeneously with soil and finally fortified with the known concentration of naphthalene $(50 \mathrm{mg} /$ $\mathrm{kg})$ and phenanthrene $(100 \mathrm{mg} / \mathrm{kg})$ into the soil. Soil samples were collected, air-dried, sieved by $2-\mathrm{mm}$ sieve and stored at room temperature in plastic containers for further characterization.

Before spiking contaminants in control (soil without biochar) and biochar-amended soil, the physico-chemical parameters were studied (represented in Table 1). The $\mathrm{pH}$ was measured by using a $\mathrm{pH}$ meter $(2: 5 \mathrm{~m} / \mathrm{v})$ (Cyberscan $\mathrm{pH}$ tutor, EUTECH), electrical conductivity (EC) was measured by using conductivity meter $(2: 5 \mathrm{~m} / \mathrm{v})$ (Laboratory testing procedure for soil sample analysis ISO 9001: 2000) (CM-183, ELICO), soil organic carbon (SOC) was analyzed by the Walkley-Black method or wet digestion method, and CEC was determined by using flame photometer (CL-378, ELICO). The amount of $\mathrm{Mg}, \mathrm{Cu}, \mathrm{Mn}, \mathrm{Zn}$ and Fe was determined by using atomic absorption spectrophotometer (Shimadzu AA-6300, Japan \& GFA-EX7i), and $C a$ and $K$ concentration were determined by using flame photometer.

\subsubsection{Selected plant species}

In this study, berseem (Trifolium alexandrinum) was used as a test crop, Mescavi variety, procured from Chaudhary Charan Singh Haryana Agriculture University (CCSHAU), Hisar, India. Plant samples from pots having different concentration of biochar $(0 \%, 1 \%, 5 \%$ and $10 \%)$ were taken on an interval of approximately 60 days. The soil and plants samples were studied in replicates. Four different types of treatment sets are designed in Table 4 in electronic supplementary material.
Table 1 Soil and biochar characteristics used in experiment

\begin{tabular}{|c|c|c|c|}
\hline S. no. & Characteristics & Soil & Biochar type \\
\hline 1. & Soil and biochar type & Sandy soil & Alkaline \\
\hline 2. & Soil texture & $\begin{array}{l}\text { - Sand: } 85.09 \% \\
\text { - Silt: } 10.71 \% \\
\text { - Clay: } 4.20 \%\end{array}$ & ND \\
\hline 3. & Water holding capacity (\%) & 25.7 & 93 \\
\hline 4. & Biochar feedstock & - & Prosopis juliflora \\
\hline 5. & pH (1:10 solid water suspension) & 8.09 & 8.54 \\
\hline 6. & $\begin{array}{l}\text { Electrical conductivity }(\mathrm{EC}) \mathrm{ds} / \mathrm{m} \text { (1:10 soil } \\
\text { water extract) }\end{array}$ & 1.31 & 1.43 \\
\hline 7. & Cation exchange capacity $(\mathrm{cmol} / \mathrm{kg})$ & 9.24 & 16.9 \\
\hline 8. & Total organic $\mathrm{C}\left(\mathrm{g} \mathrm{kg}^{-1}\right)$ & 109 & 870 \\
\hline 9. & Total $\mathrm{Na}\left(\mathrm{g} \mathrm{kg}^{-1}\right)$ & 0.21 & 0.68 \\
\hline 10. & Total K $\left(\mathrm{g} \mathrm{kg}^{-1}\right)$ & 0.8 & 0.83 \\
\hline 11. & Total $\mathrm{Mg}\left(\mathrm{g} \mathrm{kg}^{-1}\right)$ & 0.04 & 0.12 \\
\hline 12. & Total Ca $\left(\mathrm{g} \mathrm{kg}^{-1}\right)$ & 3.09 & 10.6 \\
\hline 13. & Total Cu $\left(\mathrm{g} \mathrm{kg}^{-1}\right)$ & 0.01 & 0.26 \\
\hline 14. & Total Mn $\left(\mathrm{g} \mathrm{kg}^{-1}\right)$ & 0.19 & ND \\
\hline 15. & Total $\mathrm{Ni}\left(\mathrm{g} \mathrm{kg}^{-1}\right)$ & 0.01 & 0.04 \\
\hline 16. & Total Zn $\left(\mathrm{g} \mathrm{kg}^{-1}\right)$ & 0.03 & ND \\
\hline 17. & Total Fe $\left(\mathrm{g} \mathrm{kg}^{-1}\right)$ & 0.05 & 0.01 \\
\hline
\end{tabular}

Values are mean of triplicate samples, and elemental analysis was done by using EDX 


\subsection{Proximate analysis of biochar}

The moisture content, volatile matter and ash content of biochar were determined by using ASTM standard method-D1762-84 [5] (shown in Table 5 in electronic supplementary material).

\subsection{Ultimate or Elemental analysis of biochar}

Different elements $\mathrm{C}, \mathrm{O}, \mathrm{Cu}, \mathrm{Mn}, \mathrm{Ni}, \mathrm{Zn}$ and Fe were determined by using EDX. Hydrogen, sulfur and nitrogen were analyzed by using ASTM standard method-D3176-89 [6] (represented in Table 1 and Table 5 in electronic supplementary material).

\subsection{Fortification of soil sample}

The soil sample without any treatment (control) was collected, dried and sieved by passing through 2-mm sieve. The fortification was carried out by spiking the $50 \mathrm{mg} / \mathrm{kg}$ naphthalene and $100 \mathrm{mg} / \mathrm{kg}$ phenanthrene for further analysis of PAH recovery (\%). The spiked samples were subjected to the same extraction procedure as explained in the supplementary materials.

\subsection{Extraction efficiency}

For calculating the extraction efficiency and derivatization of naphthalene and phenanthrene, the standard solutions were processed (Table 6 in electronic supplementary material). The quantity of PAHs in extracts was estimated on the basis of peak area by using formula given in Eq. 5 . Both PAHs were detected by matching their retention time $( \pm 0.5 \mathrm{~min})$ with those of pure standards. The standard peaks of phenanthrene and naphthalene (Conc. v/s peak area) are represented in Fig. 7 in electronic supplementary material.

\subsection{Biomass measurement}

Aboveground plant height and dry biomass were observed at different time intervals. Roots of each plant were cleaned properly with running water, and plants were sorted manually. Fresh plant biomass and dry plant biomass (oven dry plants at $65^{\circ} \mathrm{C}$ for $48 \mathrm{~h}$ ) were recorded, and plant samples were grind in the electric stainless steel grinder and sieved by using $0.5-\mathrm{mm}$ sieve and stored in plastic containers at room temperature for further analysis.

\subsection{Plant available nutrients}

The concentration of available plant nutrients $(\mathrm{Mn}, \mathrm{Fe}, \mathrm{Cu}$, $\mathrm{Zn}$ and $\mathrm{Mg}$ ) was analyzed by digesting the $1.0 \mathrm{~g}$ oven dried tissue, in diacid mixture (nitric acid and perchloric acid) (9:1) under fume hood (CHF-42-SS) and filtered by using Whatman filter paper No. 1, makeup total volume $50 \mathrm{ml}$ and analyzed by using atomic absorption spectrophotometer. Total $\mathrm{Na}, \mathrm{Ca}$ and $\mathrm{K}$ concentrations were determined by using flame photometer (Elico, CL 378) [39].

\subsection{Plant chlorophyll content}

Chlorophyll 'a', 'b' and total chlorophyll content were determined by using an equation given by [10].

Extraction of chlorophyll Fresh leaf tissues (100 mg) were homogenized in $80 \%$ acetone in a vial and centrifuged at $5000 \mathrm{rpm}$ for approximately $5 \mathrm{~min}$. The supernatant was transferred to a graduated tube and made volume $10 \mathrm{ml}$ with $80 \%$ acetone and assayed immediately. Absorbance of supernatant was recorded at $645 \mathrm{~nm}$ and $663 \mathrm{~nm}$ in a UV-Visible spectrophotometer (BioMate 3S, Thermo scientific, India) against 80\% acetone used as blank.

\subsection{Statistical analysis}

All experiments were performed in three replicates. The data were homogeneous and normally distributed. For comparison between all set of treatments at different durations, two-way ANOVA and Duncan test were performed by using SPSS V.18 and presented as mean of three replicates \pm SE level of significance between treatments was checked at $P \leq 0.05$.

\section{Results}

\subsection{Plant height}

The significant increase in plant height was observed at $P \leq 0.05$ significance level in soil amended with $5 \%$ and $10 \%$ biochar concentration (as represented in Fig. 1). Initially, the plant height was observed to be $15.47 \mathrm{~cm}$ (December 2015), $52.50 \mathrm{~cm}$ (February 2016) and in April 2016 it was found to be $107.61 \mathrm{~cm}$ in control soil (A0), without biochar amendment. The percent increase was observed as $70.53 \%$ (December to February), 51.21\% (February to April) and $85.62 \%$ (December to April). The influences of biochar addition on plant growth parameters were highly dependent on soil quality. The significant effect was observed with biochar addition in soil as compared to control.

The maximum percent increase was noticed in December 2015 sampling which efficiently changed with age or time period (from December 2015 to April 2016). In soil having $5 \%$ biochar dose (A2) without any PAHs 
Fig. 1 Mean \pm SE (standard error) with different letters denotes significant differences in plant height and mean value with the same letter are not significantly differ at $P \leq 0.05$ (Duncan multiple comparison test)

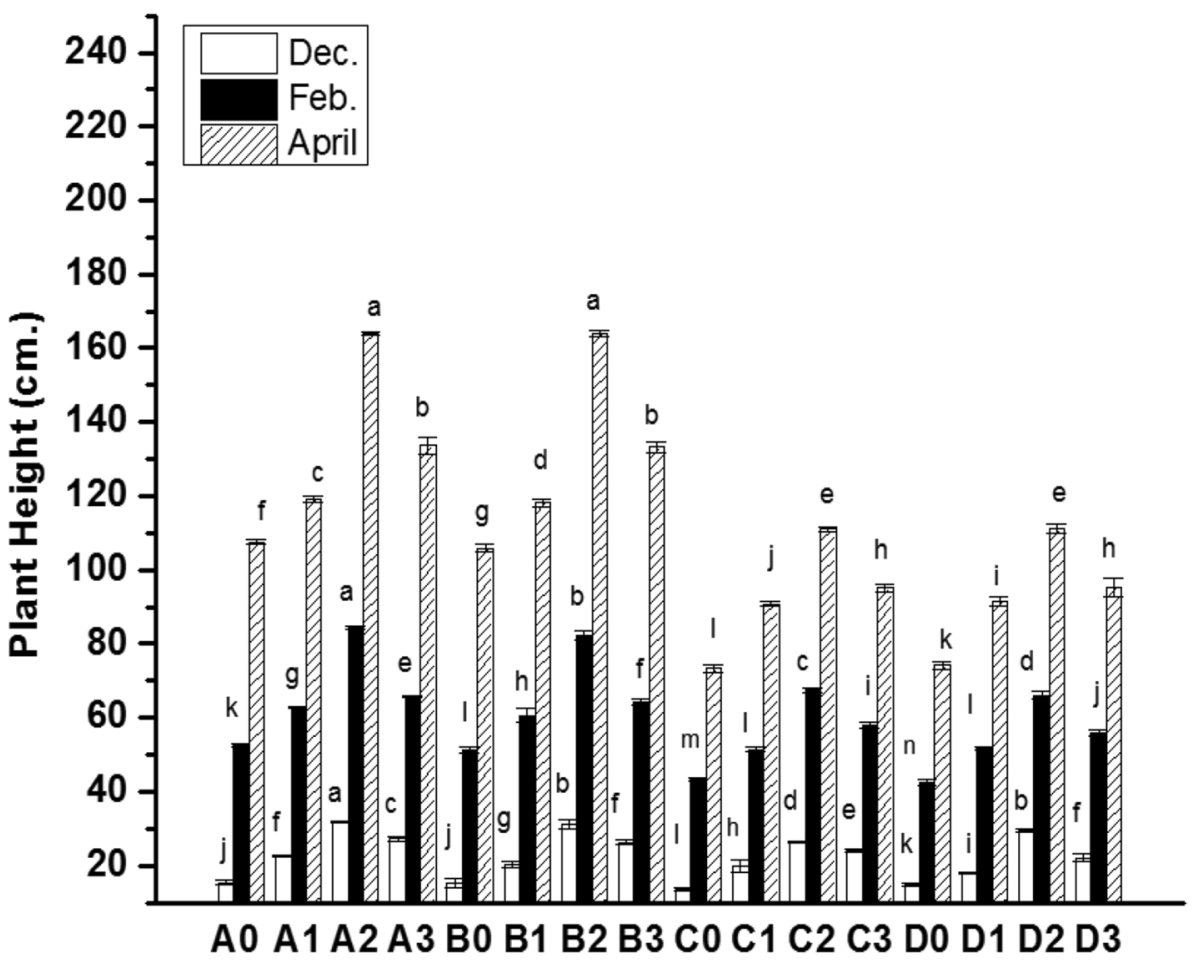

Treatments contamination, the maximum percent increase was observed $51.26 \%$ in December and $35.18 \%$ in April as compared to control (A0). In soil having $10 \%$ biochar dose (A3), the maximum percent increase was reported to be 44.15\% in December and $21.90 \%$ in April as compared to control soil (A0). The percent increase was observed to be $51.80 \%$ (December) and 35.08\% (April) in soil mixed with $5 \%$ biochar and $50 \mathrm{mg} / \mathrm{kg}$ naphthalene dose (B2) as compared with naphthalene contaminated soil without biochar application (B0). On the other hand, if we compared $5 \%$ biochar-amended soil spiked with $100 \mathrm{mg} / \mathrm{kg}$ phenanthrene dose (C2) as compared with phenanthrene-contaminated soil without any biochar dose effect (CO), the percent increase observed was $46.44 \%$ (December) and $30.16 \%$ (April). Soil spiked with combined dose of both naphthalene and phenanthrene mixed with 5\% biochar concentration (D2) was showed to be $48.12 \%$ (December) and $31.30 \%$ (April) increase in plant height as compared to soil without biochar application rate, but spiked with combined contaminant dose effect (D0).

\subsection{Plant dry biomass}

Application of biochar on naphthalene- and phenanthrene-polluted and naphthalene- and phenanthreneunpolluted soil samples was significantly $(P \leq 0.05)$ increased. The mean values of plant biomass are represented in Fig. 2. In the proposed experiment, initially, the plant biomass was observed to be $1.80 \mathrm{~g}$ (December 2015), $11.50 \mathrm{~g}$ (February) and in April 2016 it was $21.46 \mathrm{~g}$ in control soil (A0). Plant biomass increased with each sampling period, but their percent increase effectively changed with different time intervals and with biochar application rate. The percent increase was observed to be $84.34 \%$ (December to February), 46.41\% (February to April) and $91.61 \%$ (December to April).

The highest increase in plant biomass was observed with $5 \%$ and $10 \%$ biochar dose effect as compared to other treatments. In soil having 5\% biochar dose (A2) without any $\mathrm{PAHs}$ contamination, the maximum percent increase was reported as $66.48 \%$ (December) and $34.19 \%$ (April) as compared to control (A0) without biochar application. In soil amended with $10 \%$ biochar concentration, the percent increase was observed to be $60.95 \%$ (December) and $29.43 \%$ (April). Moreover, the percent increase was observed as 64.09\% (December) and 34.67\% (April) in biochar-amended soil spiked with $50 \mathrm{mg} / \mathrm{kg}$ naphthalene dose (B2) as compared with biochar non-amended soil (B0). Soil spiked with $100 \mathrm{mg} / \mathrm{kg}$ phenanthrene dose with $5 \%$ biochar application rate (C2) showed significant difference as compared with phenanthrene-contaminated soil without biochar dose effect (C0). Therefore, the percent increase was found to be $56.56 \%$ (December) and $28.86 \%$ (April) in 5\% biochar-amended soil (C2) as compared to C0. Soil spiked with combined dose of both naphthalene and phenanthrene mixed with $5 \%$ biochar concentration (D2) 
Fig. 2 Mean \pm SE (standard error) with different letters denotes significant differences in aboveground biomass and mean value with the same letter is not significantly different at different time intervals at $P \leq 0.05$ (comparisons using a Duncan multiple comparison test at)

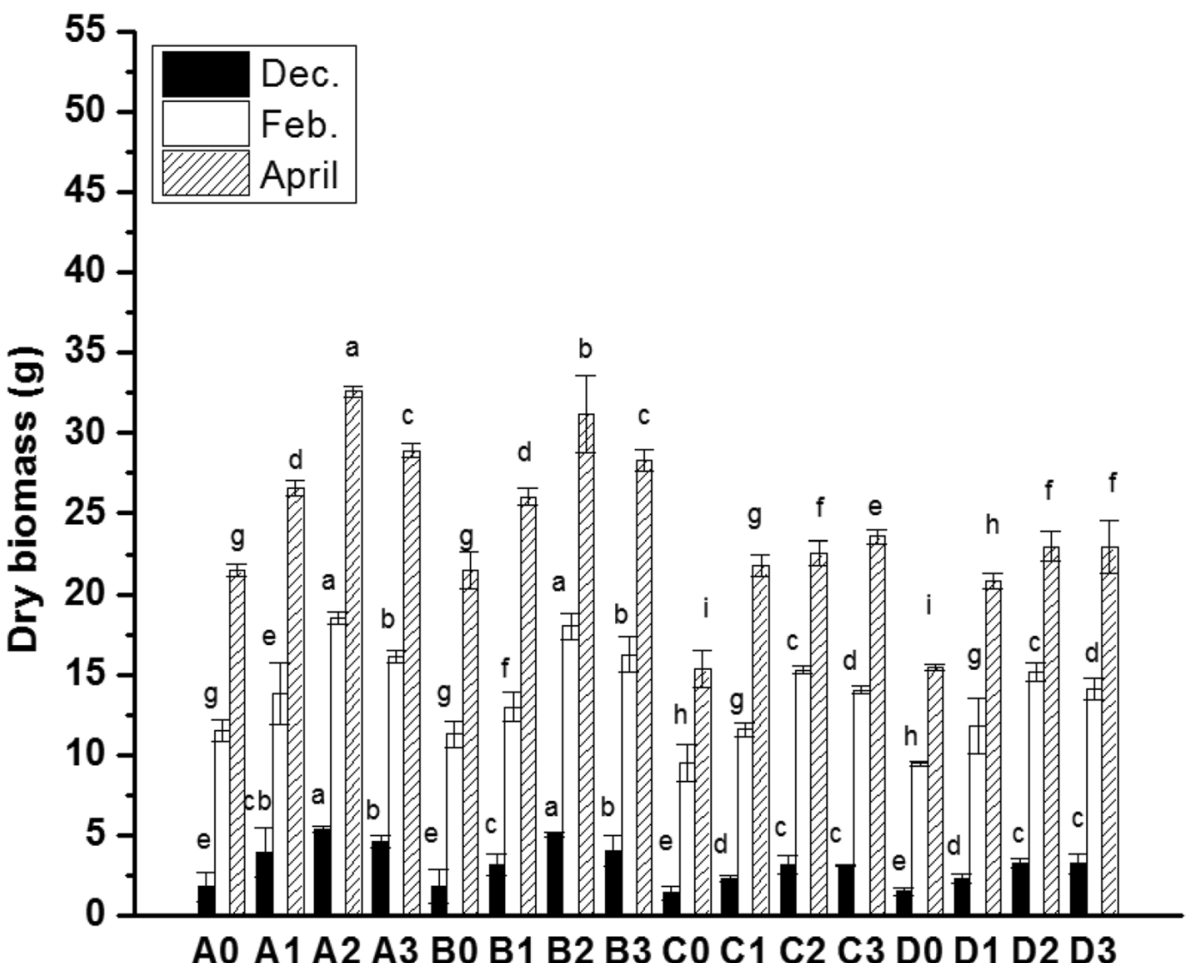

Treatments showed 54.29\% (December) and 30.34\% (April), increase in plant dry biomass as compared to D0, i.e., biochar nonamended soil but spiked with combined contaminant dose of both naphthalene and phenanthrene.

\subsection{Plant chlorophyll content}

The analysis of variance showed that the non-significant results were observed in different set of treatments at $P \leq 0.05$ significance level (as represented in Fig. 3). Initially (December 2015 sampling), the plant chlorophyll content was observed to be $1.26 \mathrm{mg} / \mathrm{ml}$ in control soil (A0) and $1.29 \mathrm{mg} / \mathrm{ml}$ in $10 \%$ biochar-amended soil (A3). Finally, in April (2016) sampling period, the concentration was found to be $1.18 \mathrm{mg} / \mathrm{ml}$ in control (A0) and 1.47 in $10 \%$ biocharamended soil (A3).

\subsection{Plant tissue analysis}

The analysis of plant available nutrients with an addition of different doses of biochar is represented in Table 2. The biochar applications significantly affect the plant tissue macronutrients ( $\mathrm{K}, \mathrm{Mg}$ and $\mathrm{Ca}$ ) concentration at $P \leq 0.05$ level of significance (as represented in Table 2). Biochar application rate of $1 \%, 5 \%$ and $10 \%$ results into $58 \%$, $83.9 \%$ and $92.3 \%$ increase in $\mathrm{K}$ concentration $15.8 \%, 28.7 \%$ and $45.9 \%$ increase in $\mathrm{Mg}$ concentration, 3.4\%, 9.2\% and
$23.64 \%$ increases in plant Ca concentration and $10.31 \%$, $12.94 \%$ and $13.29 \%$ increase in plant Cu concentration, respectively, as compared to control.

Furthermore, 1.65\% increases in Fe concentration was observed only in soil amended with $1 \%$ biochar dose. Furthermore, in case of $5 \%$ and $10 \%$ biochar, the Fe concentration was effectively reduced. Soil amended with different biochar doses showed effective loss in Mn concentration in sandy soil. The non-significant results were studied for soil Zn content. 1\% biochar dose did not show any significant increase in soil $Z n$ content (the calculated value was as same as in control). On the other hand, $\mathrm{Zn}$ concentration effectively decreased with increasing biochar application rate in soil ( $5 \%$ and $10 \%)$.

\subsection{BCF calculated}

The statistical analysis revealed a significant $(P \leq 0.05)$ decrease in BCF value due to addition of different concentration of biochar $(1 \%, 5 \%$ and $10 \%)$ in soil. The significant changes in BCF values were observed only in two types of sample sets (Set No. 3 and 4), spiked with phenanthrene and mixed dose of both (naphthalene and phenanthrene). Naphthalene was not detected in any sample analyzed by GC-FID.

The BCF value reduced from 123.1 to $18.6 \%$ (December 2015), and in April (2016) duration it was reduced from 
Fig. 3 Mean \pm SE (standard error) with the same letter denotes chlorophyll content of all treatment sets at different time intervals (December 2015 and April 2016) and is not significantly different from each other. Comparisons using a Duncan multiple comparison test at $P \leq 0.05$

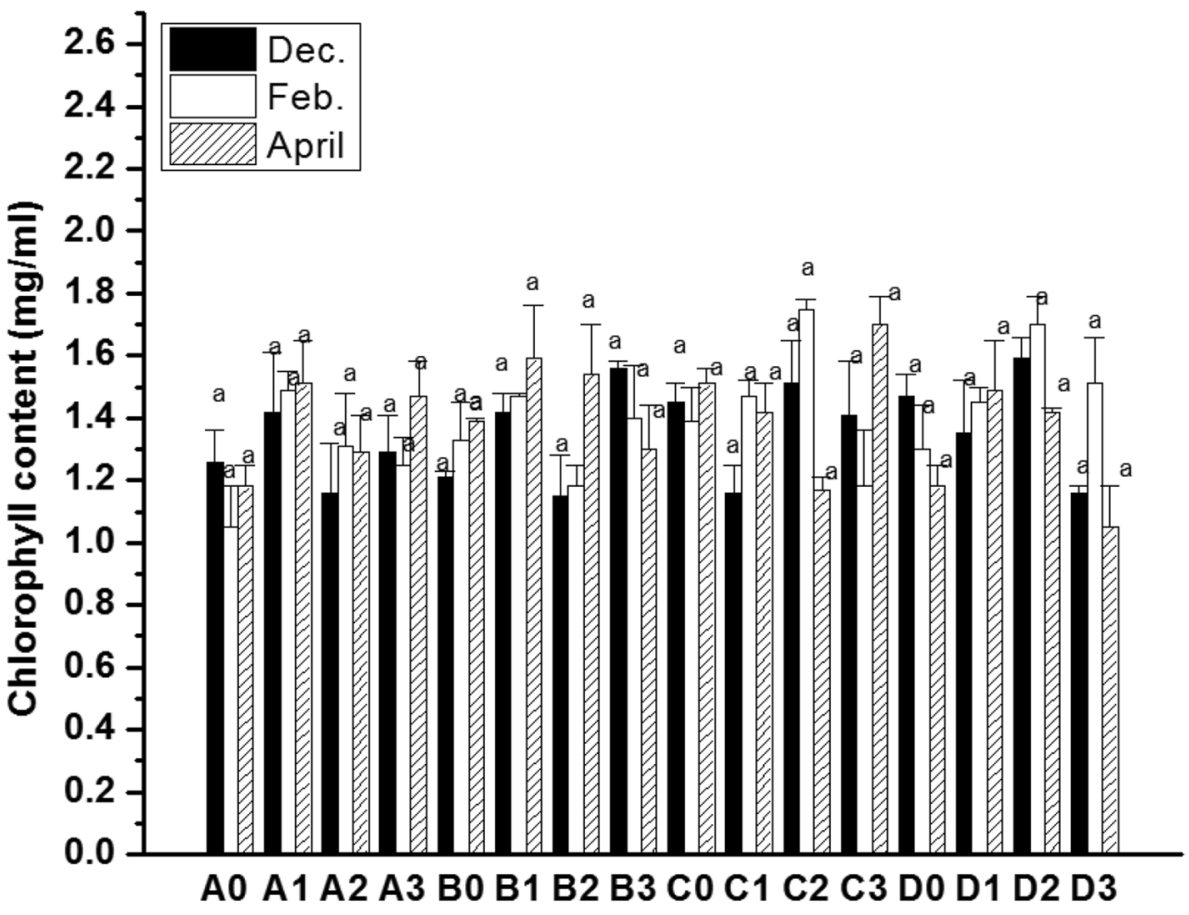

Treatments
Table 2 Macronutrients and micronutrients study in biochar-amended and biochar non-amended soil samples

\begin{tabular}{lrrrr}
\hline Plant available nutrients $(\mathrm{mg} / \mathrm{kg})$ & & \\
\hline Macronutrients \& & \multicolumn{1}{l}{ T1 } & \multicolumn{1}{l}{ T2 } & \multicolumn{1}{l}{ T3 } & \multicolumn{1}{l}{ T4 } \\
micronutrients & Mean \pm SE & \multicolumn{1}{l}{ Mean \pm SE } & \multicolumn{1}{l}{ Mean \pm SE } & \multicolumn{1}{c}{ Mean \pm SE } \\
\hline 1. Potassium (K) & $51.43 \pm 0.37^{\mathrm{d}}$ & $122.47 \pm 0.50^{\mathrm{c}}$ & $321.38 \pm 0.31^{\mathrm{b}}$ & $675.37 \pm 1.48^{\mathrm{a}}$ \\
2. Magnesium (Mg) & $72.03 \pm 0.54^{\mathrm{d}}$ & $85.63 \pm 0.23^{\mathrm{c}}$ & $101.03 \pm 1.13^{\mathrm{b}}$ & $133.27 \pm 0.82^{\mathrm{a}}$ \\
3. Calcium (Ca) & $514.67 \pm 0.32^{\mathrm{d}}$ & $532.90 \pm 0.90^{\mathrm{c}}$ & $567 \pm 0.58^{\mathrm{b}}$ & $674.08 \pm 1.23^{\mathrm{a}}$ \\
4. Zinc (Zn) & $2212.33 \pm 0.88^{\mathrm{a}}$ & $2212 \pm 1.53^{\mathrm{a}}$ & $2156.33 \pm 14.84^{\mathrm{b}}$ & $1960 \pm 0.58^{\mathrm{c}}$ \\
5. Iron (Fe) & $130.47 \pm 0.29^{\mathrm{b}}$ & $132.66 \pm 0.67^{\mathrm{a}}$ & $129.79 \pm 0.15^{\mathrm{c}}$ & $129.56 \pm 0.26^{\mathrm{c}}$ \\
6. Manganese (Mn) & $41.27 \pm 0.51^{\mathrm{a}}$ & $32.83 \pm 0.09^{\mathrm{b}}$ & $29.70 \pm 0.46^{\mathrm{c}}$ & $29.88 \pm 0.06^{\mathrm{c}}$ \\
7. Copper (Cu) & $8.61 \pm 0.07^{\mathrm{c}}$ & $9.60 \pm 0.08^{\mathrm{b}}$ & $9.89 \pm 0.31^{\mathrm{a}}$ & $9.93 \pm 0.19^{\mathrm{a}}$ \\
\hline
\end{tabular}

Here, $\mathrm{T} 1=$ control $(\mathrm{A} 0)$ or soil without biochar, $\mathrm{T} 2=$ soil $+1 \%$ biochar $(\mathrm{A} 1), \mathrm{T} 3=$ soil $+5 \%$ biochar $(\mathrm{A} 2)$, and $\mathrm{T} 4=$ soil $+10 \%$ biochar (A3)

Means \pm SE (standard error) within column followed by the same superscripts are not significantly different and mean values with different superscripts denote significant difference between all treatments. Comparisons using a Duncan multiple comparison test at $(P \leq 0.05)$. Macronutrients $(\mathrm{K}, \mathrm{Ca}, \mathrm{Mg})$ and micronutrients ( $\mathrm{Zn}, \mathrm{Fe}, \mathrm{Mn}, \mathrm{Cu}$ )
106.73 to $4.46 \%$, with increased biochar application rate at $10 \%$. However, in mixed contaminated soil, the range of $B C F$ value was significantly decreased $(P \leq 0.05)$ from 19.3 to $4.69 \%$ (December 2015) and $16.73 \%$ to $1.32 \%$ (April 2016) as represented in Table 3. The non-significant mean difference was found after comparing both durations (December 2015 and April 2016). All samples having different treatments were significantly different from each other at $P \leq 0.05$ significance level. BCF value effectively decreased with increased biochar application rate $(10 \%>5 \%>1 \%)$ due to the increased surface adsorption capacity of biochar (which depends upon production temperature and raw material used during pyrolysis) with increased concentration.

\subsection{Removal efficiency (\%)}

The $\mathrm{PAH}$ removal percentage significantly increased in biochar-amended soil at $P \leq 0.05$ significance level as compared to control $(10 \%>5 \%>1 \%>$ control). The maximum removal percentage in phenanthrene-contaminated soil varied from $66.58 \%$ (C1) to $85.01 \%$ (C3) in December, 
Table 3 Shows the BCF values and \% removal efficiency of phenanthrene-contaminated soil at different time interval in amended and non-amended biochar soil

\begin{tabular}{|c|c|c|c|c|}
\hline \multirow[t]{2}{*}{ Treatments } & \multicolumn{2}{|c|}{ December sampling } & \multicolumn{2}{|l|}{ April sampling } \\
\hline & $\mathrm{BCF}$ value $\pm \mathrm{SE}$ & $\begin{array}{l}\text { Removal efficiency } \\
(\%)\end{array}$ & $\mathrm{BCF}$ value $\pm \mathrm{SE}$ & $\begin{array}{l}\text { Removal } \\
\text { efficiency } \\
(\%)\end{array}$ \\
\hline \multicolumn{5}{|l|}{ Set 3} \\
\hline $\mathrm{CO}$ & $123.1 \pm 0.96^{\mathrm{a}}$ & ND & $106.73 \pm 0.33^{\mathrm{a}}$ & ND \\
\hline $\mathrm{C} 1$ & $41.5 \pm 0.40^{b}$ & $66.58^{d}$ & $26.00 \pm 0.15^{b}$ & $46.25^{d}$ \\
\hline $\mathrm{C} 2$ & $33.0 \pm 1.04^{c}$ & $73.42^{\mathrm{b}}$ & $24.32 \pm 0.32^{c}$ & $58.92^{c}$ \\
\hline $\mathrm{C} 3$ & $18.6 \pm 0.42^{\mathrm{e}}$ & $85.01^{\mathrm{a}}$ & $4.46 \pm 0.27^{e}$ & $77.83^{a}$ \\
\hline \multicolumn{5}{|l|}{ Set 4} \\
\hline Do & $19.3 \pm 0.32^{d}$ & ND & $16.73 \pm 0.15^{d}$ & ND \\
\hline D1 & $10.4 \pm 0.52^{f}$ & $48.07^{f}$ & $2.50 \pm 0.00^{f}$ & $39.78^{\mathrm{e}}$ \\
\hline D2 & $8.0 \pm 0.21^{g}$ & $58.94^{e}$ & $1.49 \pm 0.25^{\mathrm{g}}$ & $58.84^{c}$ \\
\hline D3 & $4.6 \pm 0.56^{h}$ & $72.90^{C}$ & $1.32 \pm 0.05^{\mathrm{h}}$ & $66.68^{b}$ \\
\hline
\end{tabular}

Here, $\quad \mathrm{CO}=$ soil + phenanthrene,$\quad \mathrm{C} 1=$ soil + phenanthrene $+1 \% \quad$ biochar,$\quad \mathrm{C} 2=$ soil + phenanthrene $+5 \%$ biochar, C3 $=$ soil + phenanthrene $+10 \%$ biochar, D0 = soil + phenanthrene + naphthalene, D1 = soil + phenanthrene + naphthalene $+1 \%$ biochar, D2 = soil + phenanthrene + naphthalene $+5 \%$ biochar, D3 = soil + phenanthrene + naphthalene $+10 \%$ biochar

ND not detected values

Means \pm SE (standard error) within column followed by the same superscripts are not significantly different and mean values with different superscripts denote significant difference between all treatments at different sampling intervals using Duncan multiple comparison test $(P \leq 0.05)$
2015 and $46.25 \%$ (C1) to $77.83 \%$ (C3) in April 2016 as compared to control (C0). However, in mixed contaminated soil, maximum removal percentage observed was $48.07 \%$ (D1) to $72.90 \%$ (D3) (December 2015) and in April 2016 the removal rate estimated was $39.78 \%$ (D1) to $66.68 \%$ (D3) as compared to control (CO). These results showed that the maximum removal percentage is observed in soil having $10 \%$ biochar concentration as compared to other treatments (as shown in Table 3).

\section{Discussion}

Our research is presumably the first attempt to study the effect of separate and combined doses of biocharamended soil on berseem growth parameters. Soil was spiked with $50 \mathrm{mg} / \mathrm{kg}$ naphthalene and $100 \mathrm{mg} / \mathrm{kg}$ phenanthrene dose having different concentrations of biochar. The plant growth parameters were examined at different time intervals in field, and samples were further stored and analyzed under laboratory conditions. The low-temperature $P$. juliflora biochar used in the experimental study had a high carbon content and ability for nutrient storage, and these results were in close proximity with $[16,20,24]$.

This study observed that the low concentration of phenanthrene was found in the plant tissue (berseem) treated with biochar. This could be due to high PAH adsorption capacity of the biochar in soil. This helps to increase the biomass of Trifolium alexandrinum (berseem) and its fodder application. The strong adsorption affinity of biochar for different ionic solutes was also revealed by different authors $[17,30]$. Biochar application in soil significantly reduces the negative effects of PAH compounds by adsorbing it on their surface porous structure. The results are in close proximity to the earlier studies on use of biochar for PAHs removal $[3,23,31,32]$. So, the proposed experimental study clearly showed that the biocharamended soil has high contaminant adsorption capacity as compared with control or biochar non-amended soil.

The biochar-amended soil showed higher PAHs removal efficiency as compared to biochar non-amended soil. As the concentration of biochar increased in the soil, the removal percentage of contaminants were also increased. The sorption of PAHs into biochar surface significantly increased overtime due to its high surface area and surface porosity.

The above results clearly show that the maximum increase in plant height was observed in pots having 5\% biochar dose followed with $10 \%, 1 \%$ and $0 \%$ as compared to other treatments. This might be due to the increased $\mathrm{pH}$ and alkaline minerals ( $\mathrm{Ca}, \mathrm{Mg}$ and $\mathrm{K}$ ) level in biocharamended soil. This effects the reduction in soil metal solubility rate, which causes the binding of contaminants directly into the biochar surface and results into the micronutrient deficiencies [26]. On the other hand, the soil spiked with PAHs concentration having different doses of biochar also shows an increased plant height as compared to biochar non-amended soil (BO, C0 and D0 treatments). 
It was due to the biochar high adsorption capacity, large surface area and porosity, which helps to adsorb all contaminants on their surface and improves plant height.

Furthermore, biochar helps to reduce the risk of PAHs uptake in plant tissues by rapid sorption mechanism [2, $3,29]$. The small amount of phenanthrene transferred in plant tissues from plant root system is further detected by GC-FID. The uptake of contaminants in plant tissue suppresses plant growth, height and yield. This problem is overcome by adding different doses of biochar in contaminated soil to reduce its effect on plant growth parameters.

The study found that the $5 \%$ application rate of biochar synthesized from $P$. juliflora biomass significantly helps to improve the berseem biomass. Followed that it was observed that biomass was also effectively increased in soil having $10 \%$ biochar application rate, than $1 \%$ and control (1st set of treatment having no contaminant dose effect as compared to other set of treatments with contaminants). This might be due to the increased soil alkaline properties and hydrogen ions concentration with different biochar application rate. Biochar amendment in soil did not show any significant increase in plant chlorophyll content at different application rates and at different time intervals. It was clear that, with increasing biochar application rates the plant nutrient level significantly increases within the sufficiency range of plant growth. The maximum percent increase was observed in case of $10 \%$ biochar followed by $5 \%, 1 \%$ and $0 \%$. The reason behind this was not clear.

\section{Conclusion}

Biochar possesses a number of characteristics that make it suitable for remediation of organic and inorganic contaminants from contaminated soil. Biochar acts as a suitable amendment in the soil as it increases the surface negative charge, nutrient retention capacity, high adsorption affinity, porosity, resistance to degradation and a high internal surface area. Soil properties can be significantly influenced by the addition of biochar and are known to enhance plant productivity and soil quality. Berseem acts as a good phytoaccumulator. Total available nutrients were increased with increase in biochar application rate.

BCF value significantly decreased with increased biochar concentration in soil ( $1 \%, 5 \%$ and $10 \%)$ as compared to control (non-biochar-amended soil). There was no negative effect studied in case of naphthalene on plant growth parameters. Biochar significantly helps to increase the plant height, biomass and total available nutrients. The maximum plant biomass and height were observed in $(5 \%$ and $10 \%)$ biochar-amended soil as compared to control. Moreover, the biomass that was harvested in the presence of biochar did not show excessive PAH concentration in plant shoot comparison with other treatments having non-biochar-amended soil. This was due to biochar highly porous structure and large surface area which adsorb all contaminants present in the soil. Therefore, the addition of biochar in soil is imperative in order to enhance soil fertility, ameliorate PAH-polluted soil and increase plant nutrient uptake. Hence, berseem production was increased worldwide with different biochar application rate.

Acknowledgements Author Varinder Kaur is highly thankful to the "Maulana Azad National Fellowship for Minority Students" formulated and funded by the Ministry of Minority Affairs and UGC-SAP for financial assistance.

\section{Compliance with ethical standards}

Conflict of interest The authors declare that there is no conflict of interests regarding the publication of this paper.

\section{References}

1. Abdel-Shafy HI, Mansour MS (2016) A review on polycyclic aromatic hydrocarbons: source, environmental impact, effect on human health and remediation. Egypt J Pet 25(1):107-123. https ://doi.org/10.1016/j.ejpe.2015.03.011

2. Adeyemi TOA, Idowu OD (2017) Biochar: promoting crop yield, improving soil fertility, mitigating climate change and restoring polluted soils. World News Nat Sci 8:27-36

3. Anyika C, Majid ZA, Ibrahim Z, Zakaria MP, Yahya A (2015) The impact of biochars on sorption and biodegradation of polycyclic aromatic hydrocarbons in soils-a review. J Environ Sci Pollut Res 22(5):3314-3341. https://doi.org/10.1007/s1135 6-014-3719-5

4. Ashraf MA, Maah MJ, Yusoff I (2014) Soil contamination, risk assessment and remediation. In: Hernandez Soriano MC (ed) Environmental risk assessment of soil contamination. Intech, Rijeka, pp 3-56. https://doi.org/10.5772/57287

5. ASTM D1762-84 (2007) Standard test method for chemical analysis of wood charcoal. ASTM International, West Conshohocken, PA 19428-2959, United States

6. ASTM D3176-89 (2002) Standard practice for ultimate analysis of coal and coke. ASTM International, West Conshohocken, PA, 1989. https://doi.org/10.1520/D3176-89R02

7. Azubuike CC, Chikere CB, Okpokwasili GC (2016) Bioremediation techniques-classification based on site of application: principles, advantages, limitations and prospects. World J Microbiol Biotechnol 32(11):180. https://doi.org/10.1007/s1127 4-016-2137-x

8. Bhatti SS, Sambyal V, Nagpal AK (2016) Heavy metals bioaccumulation in Berseem (Trifolium alexandrinum) cultivated in areas under intensive agriculture, Punjab, India. J Springerplus 5(1):173. https://doi.org/10.1186/s40064-016-1777-5

9. Butnan S, Deenik JL, Toomsan B, Antal MJ, Vityakon P (2015) Biochar characteristics and application rates affecting corn growth and properties of soils contrasting in texture and mineralogy. Geoderma 237:105-116. https://doi.org/10.1016/j.geode rma.2014.08.010

10. Chaudhary E, Sharma P (2019) Chromium and cadmium removal from wastewater using duckweed-Lemna gibba L. and ultrastructural deformation due to metal toxicity. J Phytoremediat 
21(3):279-286. https://doi.org/10.1080/15226514.2018.15226 14

11. Chen B, Yuan M (2011) Enhanced sorption of polycyclic aromatic hydrocarbons by soil amended with biochar. J Soils Sediments 11(1):62-71. https://doi.org/10.1007/s11368-010-0266-7

12. Chen B, Zhou D, Zhu L (2008) Transitional adsorption and partition of nonpolar and polar aromatic contaminants by biochars of pine needles with different pyrolytic temperatures. J Environ Sci Technol 42:5137-5143. https://doi.org/10.1021/es8002684

13. Chen B, Zhou D, Zhu L, Shen X (2008) Sorption characteristics and mechanisms of organic contaminant to carbonaceous biosorbents from water. J Sci China Ser B Chem 51(5):464-472. https://doi.org/10.1007/s11426-008-0041-4

14. Eric $L$ (2017) Sustainable agricultural reviews, vol 22. Springer, Berlin, p 328

15. Gao Y, Shen Q, Ling W, Ren L (2008) Uptake of polycyclic aromatic hydrocarbons by Trifolium pretense L. from water in the presence of a nonionic surfactant. Chemosphere 72(4):636-643. https://doi.org/10.1016/j.chemosphere.2008.02.032

16. Gruss I, Twardowski JP, Latawiec A, Medyńska-Juraszek A, Królczyk J (2019) Risk assessment of low-temperature biochar used as soil amendment on soil mesofauna. Environ Sci Pollut Res. https://doi.org/10.1007/s11356-019-05153-7

17. Houben D, Evrard L, Sonnet $P$ (2013) Mobility, bioavailability and $\mathrm{pH}$-dependent leaching of cadmium, zinc and lead in a contaminated soil amended with biochar. J Chemosphere 92(11):14501457. https://doi.org/10.1016/j.chemosphere.2013.03.055

18. https://biochar-international.org/

19. Hussain M, Farooq M, Nawaz A, Al-Sadi AM, Solaiman ZM, Alghamdi SS, Ammara U, Ok YS, Siddique KH (2017) Biochar for crop production: potential benefits and risks. J Soils Sediments 17(3):685-716. https://doi.org/10.1007/s11368-016-1360-2

20. Jiang S, Tuan N, Victor R, Yang H, Zhang D, Sik OY, Huang L (2017) Characterization of hard- and softwood biochars pyrolyzed at high temperature. Environ Geochem Health 39:403-415. https ://doi.org/10.1007/s10653-016-9873-6

21. Kaur V, Sharma P (2017) Role of biochar to improve the soil conditions (a study on Trifolium Alexandrinum). J Sci Res 6(6):510-514

22. Kaur V, Sharma P (2019) Physico-chemical characterization of biochar derived from different raw materials. Int J Sci Res Rev 8(2):451-468

23. Kuppusamy $S$, Thavamani $P$, Megharaj M, Venkateswarlu K, Naidu R (2016) Agronomic and remedial benefits and risks of applying biochar to soil: current knowledge and future research directions. J Environ Int 87:1-12. https://doi.org/10.1016/j.envin t.2015.10.018

24. Lee J, Hawkins B, Kidder M, Evans B, Buchanan AC, Day D (2016) Characterization of biochars produced from peanut hulls and pine wood with different pyrolysis conditions. BIOB 3:15. https ://doi.org/10.1186/s40643-016-0092-x

25. Lehmann J, Rillig MC, Thies J, Masiello CA, Hockaday WC, Crowley D (2011) Biochar effects on soil biota-a review. Soil Biol Biochem 43(9):1812-1836. https://doi.org/10.1016/j.soilb io.2011.04.022

26. Lucchini P, Quilliam RS, DeLuca TH, Vamerali T, Jones DL (2014) Does biochar application alter heavy metal dynamics in agricultural soil? J Agric Ecosyst Environ 184:149-157. https://doi. org/10.1016/j.agee.2013.11.018

27. Manjunath SV, Mathava K (2018) Evaluation of single and multicomponent adsorption of metronidazole, phosphate and nitrate on activated carbon from Prosopis juliflora. Chem Eng J 346:525534. https://doi.org/10.1016/j.cej.2018.04.01

28. Mia S, Dijkstra FA, Singh B (2017) Long-term aging of biochar: a molecular understanding with agricultural and environmental implications. In: Sparks D (ed) Advances in agronomy, vol 141.
Academic Press, Cambridge, pp 1-51. https://doi.org/10.1016/ bs.agron.2016.10.001

29. Nartey OD, Zhao B (2014) Biochar preparation, characterization, and adsorptive capacity and its effect on bioavailability of contaminants: an overview. Adv Mater Sci Eng. https://doi. org/10.1155/2014/715398

30. Nigussie A, Kissi E, Misganaw M, Ambaw G (2012) Effect of biochar application on soil properties and nutrient uptake of lettuces (Lactuca sativa) grown in chromium polluted soils. Am Eurasian J Agric Environ Sci 12(3):369-376. https://pdfs.seman ticscholar.org/ffb5/e16d49f0b49debdd7fa3f874c4a25d28ad4 4.pdf

31. Oleszczuk P, Hale SE, Lehmann J, Cornelissen G (2012) Activated carbon and biochar amendments decrease pore-water concentrations of polycyclic aromatic hydrocarbons (PAHs) in sewage sludge. J Bioresour Technol 111:84-91. https://doi.org/10.1016/j. biortech.2012.02.030

32. Oleszczuk P, Josko I, Futa B, Pasieczna-Patkowska S, Palys E, Kraska P (2014) Effect of pesticides on microorganisms, enzymatic activity and plant in biochar-amended soil. J Geoderma 214:10-18. https://doi.org/10.1016/j.geoderma.2013.10.010

33. Oluseyi T, Olayinka K, Alo B, Smith RM (2011) Comparison of extraction and clean-up techniques for the determination of polycyclic aromatic hydrocarbons in contaminated soil samples. Afr J Environ Sci Technol 5(7):482-493

34. Pandey LK, Lavoie I, Morin S, Park J, Lyu J, Choi S, Lee H, Han T (2018) River water quality assessment based on a multi-descriptor approach including chemistry, diatom assemblage structure, and non-taxonomical diatom metrics. Ecol Indic 84:140-151. https://doi.org/10.1016/j.ecolind.2017.07.043

35. Rawat J, Saxena J, Sanwal P (2019) Biochar: a sustainable approach for improving plant growth and soil properties. In: Abrol V (ed) Biochar-an imperative amendment for soil and the environment. IntechOpen, Rijeka. https://doi.org/10.5772/ intechopen.82151

36. Reddy SBN (2014) Biocharculture-biochar for environment and development, 1st edn. MetaMeta, Wageningen

37. Schmidt HP, Kammann C, Niggli C, Evangelou MW, Mackie KA, Abiven S (2014) Biochar and biochar-compost as soil amendments to a vineyard soil: influences on plant growth, nutrient uptake, plant health and grape quality. Agr Ecosyst Environ 191:117-123. https://doi.org/10.1016/j.agee.2014.04.001

38. Sizmur T, Quilliam R, Puga AP, Moreno-Jimenez E, Beesley L, Gomez-Eyles JL (2016) Application of biochar for soil remediation. J Agric Environ Appl Biochar Adv Barriers 63:295-324. https ://doi.org/10.2136/sssaspecpub63.2014.0046.5

39. Srivastava V, Sharma P (2013) Phytoremediation and chemically enhanced phytoextraction of heavy metals with Helianthus annuus L. varieties. Ph.D. thesis, GJUS\&T, Hisar

40. Tang J, Zhu W, Kookana R, Katayama A (2013) Characteristics of biochar and its application in remediation of contaminated soil. J Biosci Bioeng 116(6):653-659. https://doi.org/10.1016/j.jbios c.2013.05.035

41. Thavamani $P$, Megharaj $M$, Krishnamurti GSR, McFarland $R$ Naidu R (2011) Finger printing of mixed contaminants from former manufactured gas plant (MGP) site soils: implications to bioremediation. J Environ Int 37(1):184-189. https://doi. org/10.1016/j.envint.2010.08.017

42. Wang J, Xiong Z, Kuzyakov Y (2016) Biochar stability in soil: meta-analysis of decomposition and priming effects. GCB Bioenergy 8(3):512-523. https://doi.org/10.1111/gcbb.12266

43. Weber K, Quicker P (2018) Properties of biochar. Fuel 217:240261. https://doi.org/10.1016/j.fuel.2017.12.054

44. William K, Qureshi RA (2015) Evaluation of biochar as fertilizer for the growth of some seasonal vegetables. J Bioresour Manag 2(1):1 
45. Ye S, Zeng G, Wu H, Zhang C, Liang J, Dai J, Liu Z, Xiong W, Wan J, Xu P, Cheng M (2017) Co-occurrence and interactions of pollutants, and their impacts on soil remediation-a review. Crit Rev Environ Sci Technol 47(16):1528-1553. https://doi. org/10.1080/10643389.2017.1386951
Publisher's Note Springer Nature remains neutral with regard to jurisdictional claims in published maps and institutional affiliations. 